\title{
Homogenized Poly(3-hexylthiophene)/Methanofullerene Film by Addition of End-Functionalized Compatibilizer and Its Application to Polymer Solar Cells
}

\author{
Ping-Tsung Huang, Yi-Hao Chen, Bo-Yu Lin, and Wei-Ping Chuang \\ Department of Chemistry, Fu Jen Catholic University, Taipei 24205, Taiwan \\ Correspondence should be addressed to Ping-Tsung Huang; 073802@mail.fju.edu.tw
}

Received 24 July 2014; Revised 13 October 2014; Accepted 19 January 2015

Academic Editor: Harald Hoppe

Copyright ( $(2015$ Ping-Tsung Huang et al. This is an open access article distributed under the Creative Commons Attribution License, which permits unrestricted use, distribution, and reproduction in any medium, provided the original work is properly cited.

A uniformed poly(3-hexylthiophene) (P3HT) and [6,6]-phenyl- $\mathrm{C}_{61}$-butyric acid methyl ester (PCBM) blended film prepared by using spin-coating process is achieved by addition of $10 \%$ hydroxyl group end-functionalized P3HT (HOC-P3HT-COH) as a compatibilizer. Ratio of $\mathrm{P} 3 \mathrm{HT} / \mathrm{PCBM}$ on a spin-coated film has been improved from 1:1.22 on the edge and 1:0.85 in the center of substrate (substrate size, $2 \mathrm{~cm} \times 3 \mathrm{~cm}$ ) to $1: 1.03$ on the edge and $1: 0.94$ in the center for P3HT/HOC-P3HT-COH/PCBM film $(1: 0.1: 1)$. Homogeneous and reproducible polymer solar cell with an average of $3.71 \%$ power conversion efficiency under AM1.5G irradiation is fabricated with $10 \%$ HOC-P3HT-COH in P3HT/PCBM layer.

\section{Introduction}

Power conversion efficiency $(\eta)$ of organic solar cells has increased from $0.04 \%$ of a bilayer device [1] to more than $8 \%$ of bulk heterojunction (BHJ) devices [2]. A major breakthrough is the introduction of $\mathrm{BHJ}$ morphology [3]. The $\mathrm{BHJ}$ morphology creates large interfacial area between the electron donors and electron acceptors that increases the efficiency of exciton dissociation and generates higher current density $\left(J_{s c}\right)$ of the BHJ devices. Evidently, morphology of the active layer plays a very important role in the performance optimization of polymer solar cells [4]. Among the electron donors and the electron acceptors, $\mathrm{P} 3 \mathrm{HT}$ and PCBM have been widely used as model materials in the active layer for polymer solar cells. Researchers [5-12] find the performance of P3HT/PCBM based polymer solar cells highly relied on the ratio of P3HT/PCBM. Domain size of PCBM increases significantly after thermal annealing as the content of PCBM increases in the P3HT/PCBM film. This will lead to decreased interfacial area between P3HT and PCBM and will end up with lower $J_{\text {sc }}$. Additionally, hole mobility and electron mobility also vary with $\mathrm{P} 3 \mathrm{HT} / \mathrm{PCBM}$ ratio. A balanced hole and electron mobility in P3HT/PCBM blend occurs as the $\mathrm{P} 3 \mathrm{HT} / \mathrm{PCBM}$ ratio is between $1: 0.8$ and $1: 1[6,7]$. Crystalline structure of $\mathrm{P} 3 \mathrm{HT} / \mathrm{PCBM}$ film characterized by scattering techniques [8-10] also reveals a high dependency on the P3HT/PCBM ratio. Generally high performance solar cells are fabricated with P3HT/PCBM ratios between 1: 0.8 and $1: 1$ $[11,12]$.

Based on the above information, a uniformed distribution of P3HT/PCBM is crucial if a reproducible large area photovoltaic module is going to be processed. It comes to our attention to examine the distribution of P3HT/PCBM ratio across a glass substrate $(2 \mathrm{~cm} \times 3 \mathrm{~cm})$ by using spincoating process, which is the most commonly used technique in laboratory. In this study, $\mathrm{P} 3 \mathrm{HT} / \mathrm{PCBM}$ ratio across a $2 \mathrm{~cm} \times 3 \mathrm{~cm}$ glass substrate is determined by using a UVVis spectroscopy technique. Effect of P3HT/PCBM ratio on the annealed P3HT/PCBM film is characterized by optical microscopy $(\mathrm{OM})$. A synthesized hydroxyl group endfunctionalized P3HT (HOC-P3HT-COH) is added to the $\mathrm{P} 3 \mathrm{HT} / \mathrm{PCBM}$ film to control the P3HT/PCBM ratio across the glass substrate.

\section{Materials and Methods}

2.1. Materials. P3HT $\left(\bar{M}_{n}=25,000\right)$ and PCBM were purchased from Aldrich Corporation and were used without 

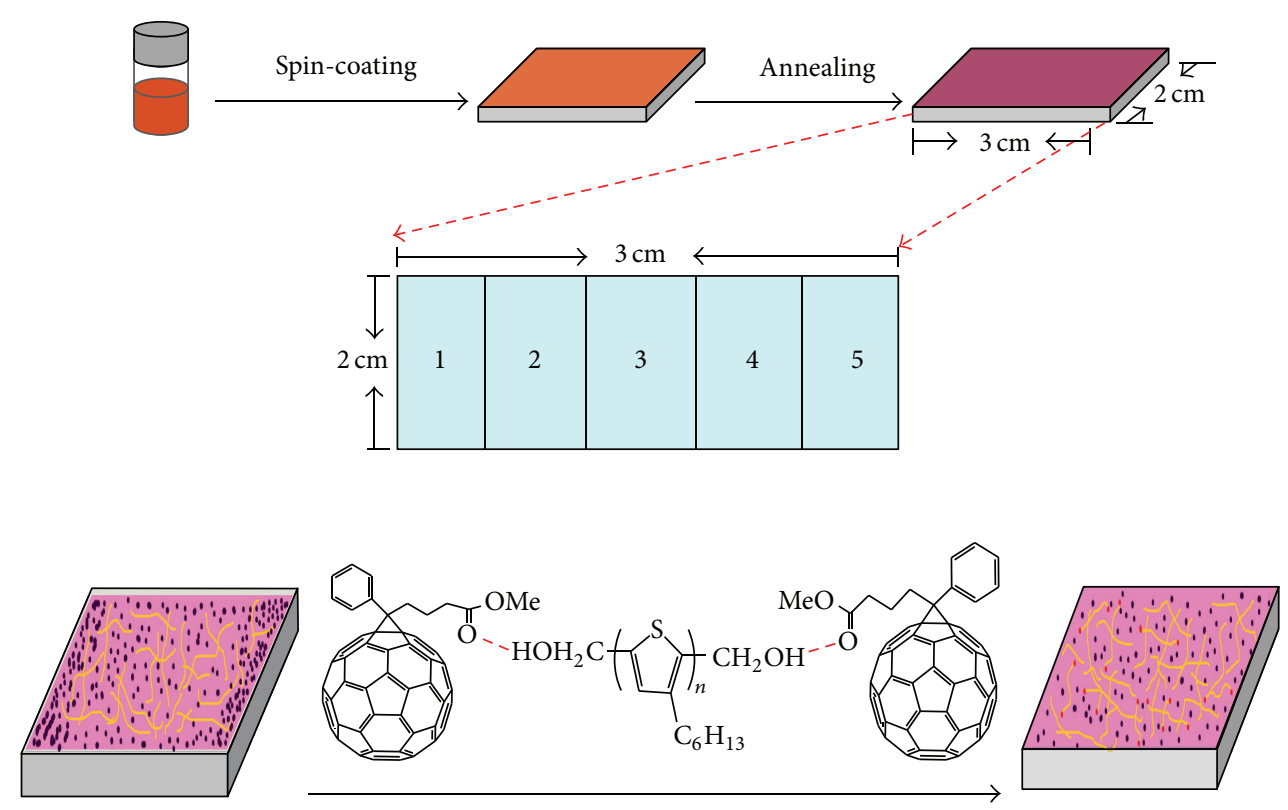

FIGURE 1: Illustration of sample preparation and identification of spin-coated P3HT/PCBM (1:1) and P3HT/HOC-P3HT-COH/PCBM (1: $0.1: 1)$ films from $1 \%$ dichlorobenzene solutions.

further purification. HOC-P3HT-COH was synthesized following a reported method [13]. The synthesized HOC-P3HT$\mathrm{COH}$ has a $\bar{M}_{n}$ of 28,700 , and a polydispersity index (PDI) of 1.89. NMR analysis [14] showed the regioregularity of the HOC-P3HT-COH was $95 \%$ and that for the purchased P3HT was $93 \%$.

2.2. Sample Preparation. $1 \%$ P3HT/PCBM (1:1) and $1 \%$ P3HT/HOC-P3HT-COH/PCBM $(1: 0.1: 1)$ in o-dichlorobenzene (ODCB, spectroscopy grade, purchased from Aldrich) were spin-coated on $2 \mathrm{~cm} \times 3 \mathrm{~cm}$ glass substrates $(500 \mathrm{rpm}$ 3 seconds and $1000 \mathrm{rpm} 10$ seconds). The spin-coated films were annealed at $150^{\circ} \mathrm{C}$ for 30 minutes for UV-Vis spectroscopy and OM measurements.

2.3. Device Fabrication. ITO substrate (sheet resistance $=$ $12 \Omega / \square$ ) was cleaned in an ultrasonic machine following by treatment with $\mathrm{O}_{2}$ plasma. A $30 \mathrm{~nm}$ PEDOT:PSS (Baytron $\mathrm{PH}$ from HC Starck) layer was coated on the ITO substrate and dried at $140^{\circ} \mathrm{C}$ for 10 min under $\mathrm{N}_{2}$ atmosphere. A $100 \mathrm{~nm}$ P3HT/PCBM (1:1) or P3HT/HOC-P3HT-COH/PCBM film (1: $0.1: 1)$ was spin-coated and annealed at $150^{\circ} \mathrm{C}$ for $10 \mathrm{~min}$. $\mathrm{Ca}(10 \mathrm{~nm}) / \mathrm{Al}(100 \mathrm{~nm})$ film was thermally evaporated as cathode at $1.0 \times 10^{-6}$ torrs.

2.4. Characterization. The molecular weight of P3HT and HOC-P3HT-COH was measured by a Viscotek DM400/LR40 Gel Permeation Chromatography (GPC) using standard polystyrene as reference. Regioregularity was determined by a Bruker AV-300 Nuclear Magnetic Resonance. UV-Visible absorption measurements were carried out with a Shimadzu UV-2101C Spectrometer. The morphology of the P3HT/PCBM and P3HT/PCBM/HOCP3HT-COH films was studied using an Olympus Optical Microscopy (OM model: $\mathrm{BH} 2$ ). I- $V$ parameters of the fabricated devices were measured by an Oriel Class A Solar Simulator 91160A under AM1.5G irradiation $\left(100 \mathrm{~mW} / \mathrm{cm}^{2}\right)$ calibrated by a NREL certified reference solar cell.

\section{Results and Discussion}

Spin-coating process [15] is a widely used technique in the research of polymer solar cells in laboratory. A blended photoactive layer such as $\mathrm{P} 3 \mathrm{HT} / \mathrm{PCBM}$ is spin-coated on a PEDOT:PSS precoated ITO substrate. This film is subject to different processes such as thermal annealing [16-18] and solvent annealing [19] before deposition of cathode materials. A polymer solar cell is ready for testing after these processes. Many factors such as composition of P3HT/PCBM [6, 7, 11, 12], annealing conditions [16-18], and solvent selection [20] affect the final performance of polymer solar cells. Composition of the $\mathrm{P} 3 \mathrm{HT} / \mathrm{PCBM}$ active layer is one of the key factors that are highly correlated with the device performance. It is shown that performance of an optimized P3HT/PCBM based polymer solar cell has a P3HT/PCBM ratio between $1: 0.8$ and $1: 1.0[6,7,11,12]$ and the performance deteriorates significantly outside this range. It becomes very important if a consistent P3HT/PCBM ratio across substrate can be achieved for a large size polymer solar cell. To examine this issue, a P3HT/PCBM $(1: 1)$ solution in dichlorobenzene is spin-coated on a $2 \mathrm{~cm} \times 3 \mathrm{~cm}$ substrate for evaluation. This substrate is divided into five regions symmetrically (Figure 1). Thicknesses of regions 1,2 , and 3 are $120 \mathrm{~nm}, 109 \mathrm{~nm}$, and $95 \mathrm{~nm}$, respectively, for P3HT/PCBM film. Thicknesses of regions 1,2 , and 3 for the P3HT/PCBM/10\% HOCP3HT-COH film are $111 \mathrm{~nm}, 113 \mathrm{~nm}$, and $112 \mathrm{~nm}$, respectively. 

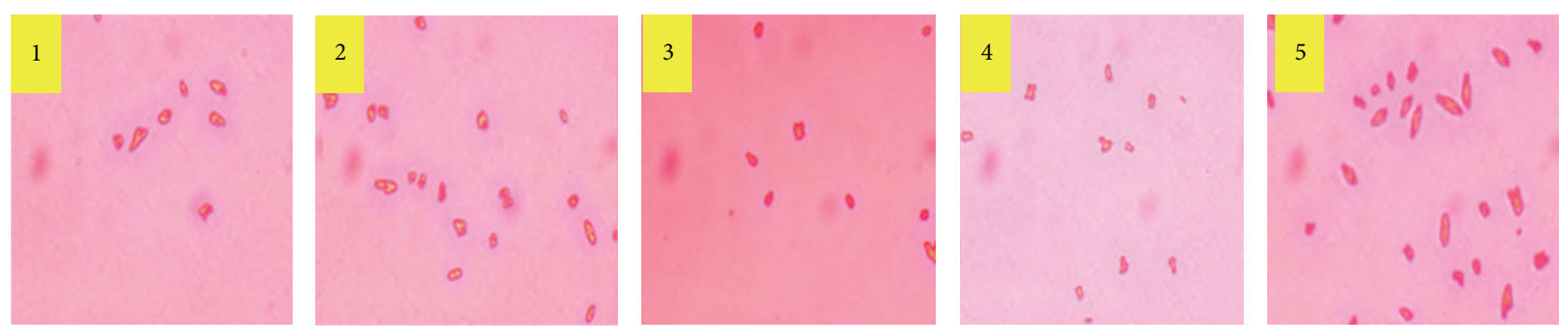

FIgURE 2: Optical microscopy photos $(\times 100)$ of the distribution of aggregated PCBM domains in annealed $\left(150^{\circ} \mathrm{C}, 30 \mathrm{~min}\right) \mathrm{P} 3 \mathrm{HT} / \mathrm{PCBM}$ (1:1) film across a $2 \mathrm{~cm} \times 3 \mathrm{~cm}$ glass substrate (edge: regions 1 and 5; center: region 3 ).

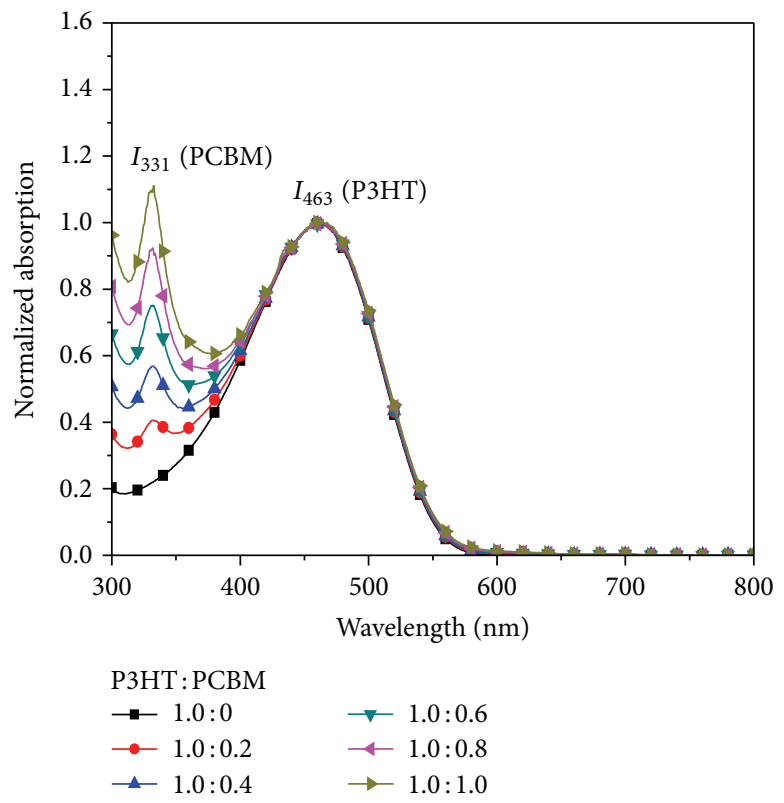

(a)

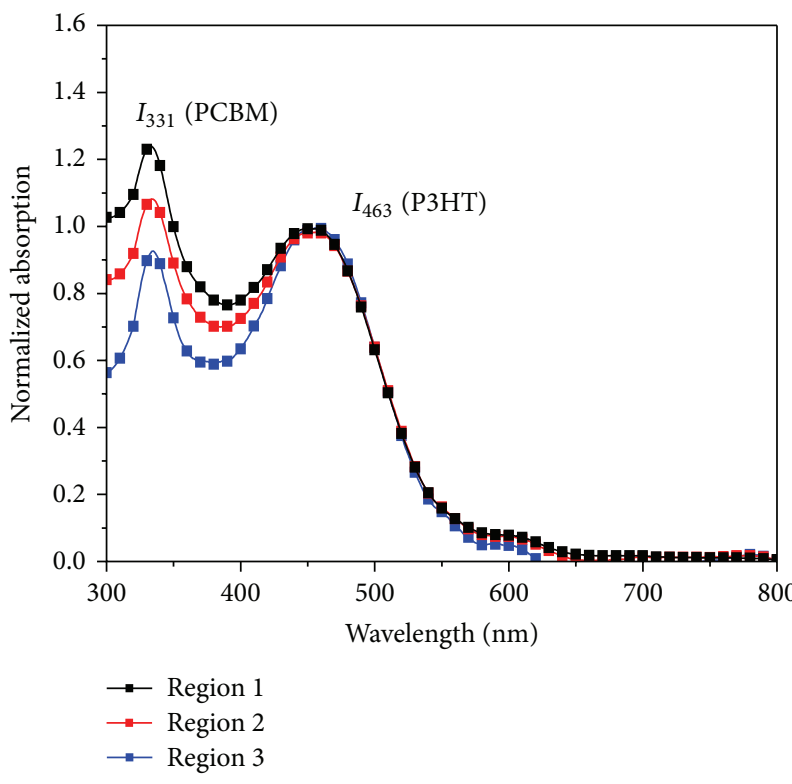

(b)

FIgURe 3: UV-Vis spectra of (a) P3HT/PCBM (1:X) (calibration curve) and (b) P3HT/PCBM (1:1) absorption in regions 1, 2 , and 3.

Compositions of $\mathrm{P} 3 \mathrm{HT} / \mathrm{PCBM}$ between center and edge are characterized.

As reported in literatures, PCBM tends to aggregate and form large domain size in a $\mathrm{P} 3 \mathrm{HT} / \mathrm{PCBM}$ film upon thermal treatment [16-18]. Therefore, it will be possible to evaluate if the distribution of PCBM/P3HT is uniformed by using an optical microscope [21]. As shown in Figure 2, density of aggregated PCBM domains increases gradually from center of the substrate (region 3) to the edge of the substrate (regions 1 and 5). This indicates a higher PCBM concentration on the edge than that in the center after the spin-coating process. To further find out the actual P3HT/PCBM ratios in these regions, a UV-Vis calibration curve is constructed (Figure 3(a)). P3HT/PCBM in different regions $(1,2$, and 3 ) is dissolved in dichlorobenzene and UV-Vis spectra are measured (assuming the coating is symmetry during the spin-coating process [15]). As shown in Figure 3(b), the relative intensity of $I_{331}$ (absorption of PCBM and P3HT) to $I_{463}$ (absorption of $\mathrm{P} 3 \mathrm{HT}$ ) increases from region 3 (center) to region 1 (edge), indicating higher PCBM concentration on
TABLE 1: List of ratio of $I_{\mathrm{PCBM}}$ to $I_{\mathrm{P} 3 \mathrm{HT}}$ and actual P3HT/PCBM compositions $(1: 1$, theoretically, without compatibilizer) in regions 1,2 , and 3 of the substrate.

\begin{tabular}{lccc}
\hline & Region 1 (edge) & Region 2 & Region 3 (center) \\
\hline$I_{\mathrm{PCBM}} / I_{\text {P3HT }}$ & 1.07 & 0.91 & 0.75 \\
P3HT $:$ PCBM & $1: 1.22$ & $1: 1.04$ & $1: 0.85$ \\
\hline
\end{tabular}

the edge (region 1). The relative intensity of $I_{\mathrm{PCBM}}$ to $I_{\mathrm{P} 3 \mathrm{HT}}$ in different regions is calculated by

$$
\frac{I_{\mathrm{PCBM}}}{I_{\mathrm{P} 3 \mathrm{HT}}}=\left[\frac{\left(I_{331}-0.2191\right)}{I_{463}}\right],
$$

where 0.2191 is the absorption intensity of $\mathrm{P} 3 \mathrm{HT}$ at $331 \mathrm{~nm}$. The corresponding $\mathrm{P} 3 \mathrm{HT} / \mathrm{PCBM}$ ratios obtained by using calibration curve are listed in Table 1. The 1\% P3HT/PCBM solution in dichlorobenzene is $1: 1$. Ideally, the ratio of P3HT/PCBM will be $1: 1$ across the substrate. The actual $\mathrm{P} 3 \mathrm{HT} / \mathrm{PCBM}$ ratio in the center is $1: 0.85$ and that on the edge 

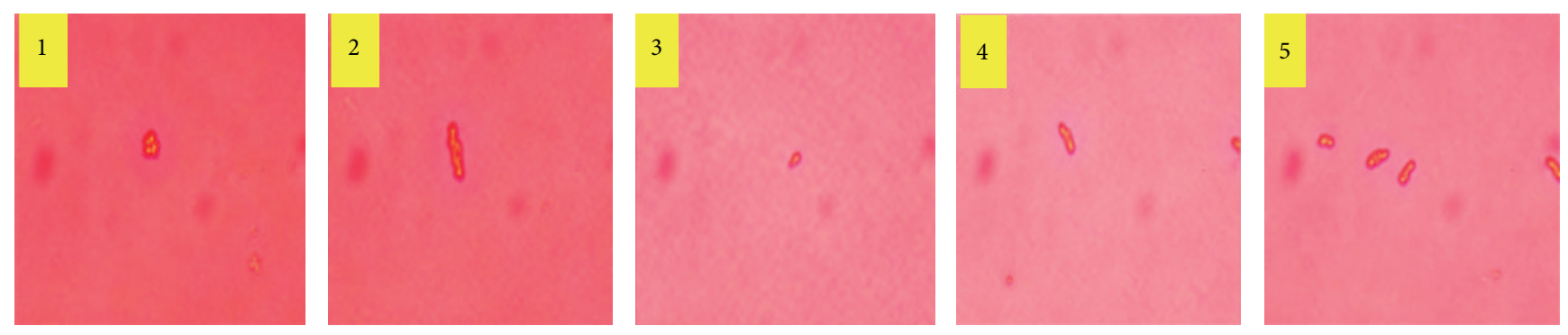

FIgURE 4: Optical microscopy photos $(\times 100)$ of the distribution of aggregated PCBM domains in annealed $\left(150^{\circ} \mathrm{C}, 30 \mathrm{~min}\right) \mathrm{P} 3 \mathrm{HT} / \mathrm{HOC}$ P3HT-COH/PCBM (1:0.1:1) film across a $2 \mathrm{~cm} \times 3 \mathrm{~cm}$ glass substrate (edge: regions 1 and 5; center: region 3 ).

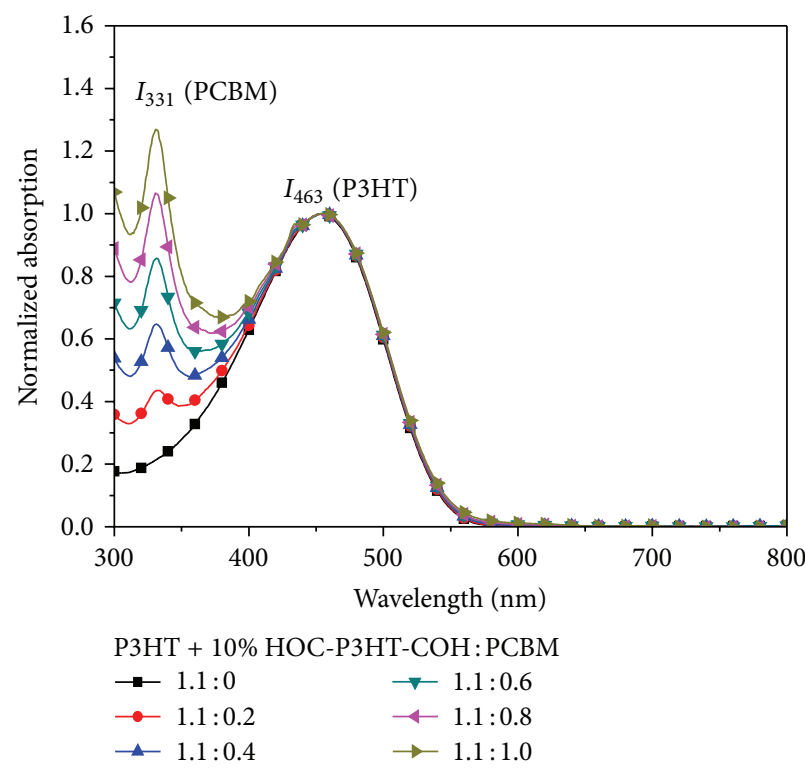

(a)

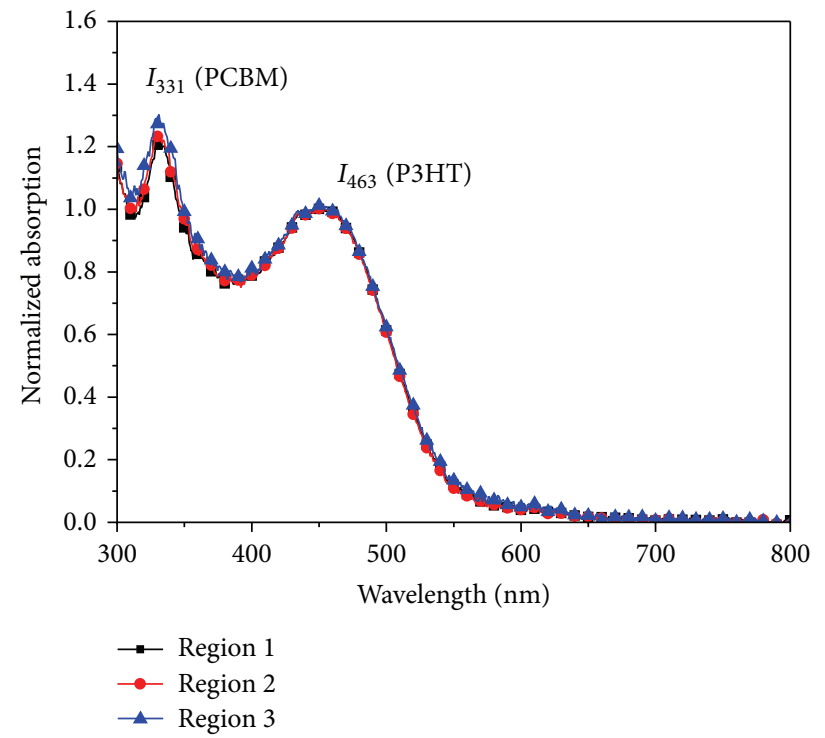

(b)

Figure 5: UV-Vis spectra of (a) P3HT/HOC-P3HT-COH/PCBM (1:0.1: X) (calibration curve) and (b) P3HT/HOC-P3HT-COH/PCBM absorption in regions 1,2 , and 3 .

is $1: 1.22$. Parts of the PCBM molecules are moved further outside the center region during the spin-coating process. $\mathrm{P} 3 \mathrm{HT}$ and PCBM are homogeneously dissolved in dichlorobenzene and they are distributed independently from each other in the solution. However, $\mathrm{P} 3 \mathrm{HT}$ is a polymeric material with many entanglements between molecules and PCBM is a small molecule with no such entanglements in solution. Upon spincoating from a common solvent-dichlorobenzene, $\mathrm{P} 3 \mathrm{HT}$ and PCBM bear with different extent of centrifugal forces [15] and exhibit different coating behavior. Parts of the PCBM are taken away from the center region and are moved to the outer region. The difference in coating behavior of $\mathrm{P} 3 \mathrm{HT}$ and $\mathrm{PCBM}$ ends up with a composition variation in $\mathrm{P} 3 \mathrm{HT} / \mathrm{PCBM}$ ratio across the substrate.

Hydroxyl group end-functionalized P3HT (HOC-P3HT$\mathrm{COH}$ ) has been proved as an effective compatibilizer in the stabilization of P3HT/PCBM blend [13]. H-bonds between the hydroxyl group of HOC-P3HT-COH and ester group of PCBM stabilize the morphology of P3HT/PCBM blend. As HOC-P3HT-COH is added to the P3HT/PCBM solution,
P3HT and PCBM molecules are physically linked through the H-bond formation. P3HT/HOC-P3HT-COH/PCBM can be treated as a physically bonded molecule during the spincoating process. As a $1 \% \mathrm{P} 3 \mathrm{HT} / \mathrm{HOC}-\mathrm{P} 3 \mathrm{HT}-\mathrm{COH} / \mathrm{PCBM}$ solution is spin-coated onto a substrate, P3HT, HOC-P3HT$\mathrm{COH}$, and PCBM do not separate. They form a uniformed coating across the substrate. As shown in Figure 4, distribution of aggregated PCBM domains is uniformed across the substrate that indicates a consistent $\mathrm{P} 3 \mathrm{HT} / \mathrm{PCBM}$ composition across the substrate. It is very important that HOCP3HT-COH not only stabilizes the P3HT/PCBM morphology, but also homogeneously disperses the PCBM in P3HT. A UV-Vis absorption calibration curve of P3HT/HOC-P3HT$\mathrm{COH} / \mathrm{PCBM}(1: 0.1: X)$ is constructed (Figure 5(a)) to determine the $\mathrm{P} 3 \mathrm{HT} / \mathrm{PCBM}$ ratio in regions 1,2 , and 3 . As shown in Figure 5(b), the relative intensity ratios of $I_{331}$ to $I_{463}$ in the region 1 , region 2 , and region 3 are very similar revealing the information that the ratios of $\mathrm{P} 3 \mathrm{HT} / \mathrm{PCBM}$ are consistent in these three regions. The actual P3HT/PCBM ratios determined by calibrated UV-Vis absorption curve are 


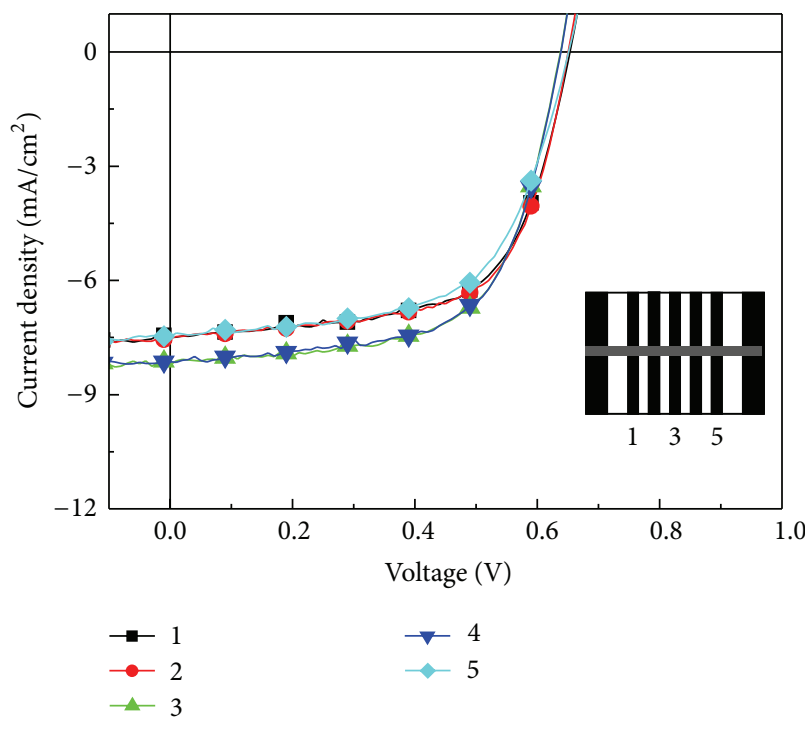

(a)

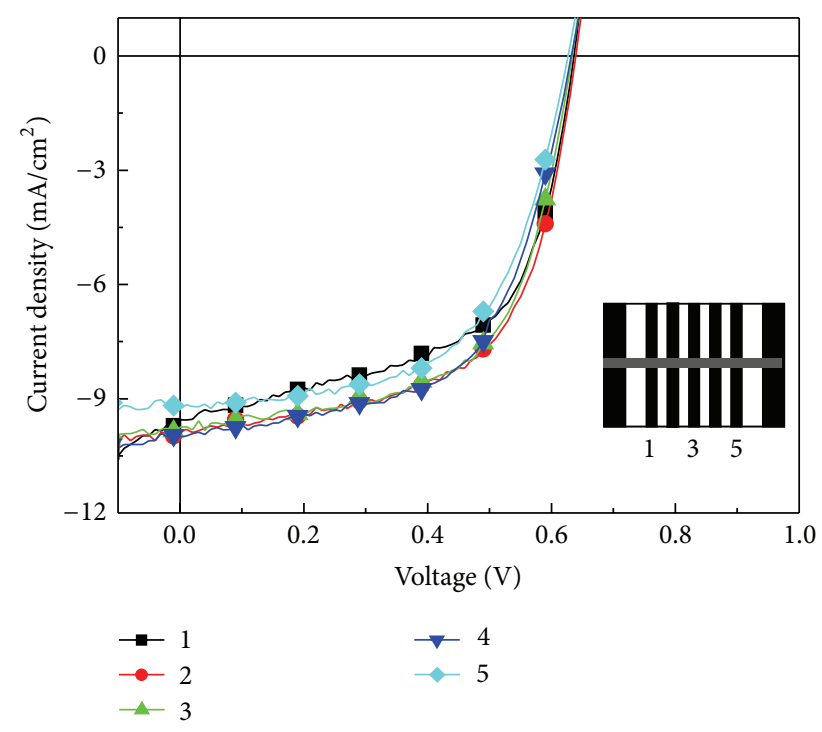

(b)

Figure 6: $J$ - $V$ curves of (a) P3HT/PCBM (1:1) and (b) P3HT/HOC-P3HT-COH/PCBM $(1: 0.1: 1)$ based polymer solar cells with a device structure of ITO/PEDOT:PSS $(40 \mathrm{~nm}) /$ active layer $(100 \mathrm{~nm}) / \mathrm{Ca} / \mathrm{Al}$ in different regions $(1-5)$ of the same substrate.

TABLE 2: List of ratio of $I_{\mathrm{PCBM}}$ to $I_{\mathrm{P} 3 \mathrm{HT}}$ and actual PCBM/P3HT* compositions ( $1: 1.1$, theoretically, with compatibilizer) in regions 1 , 2 , and 3 of the substrate.

\begin{tabular}{lccc}
\hline & Region 1 (edge) & Region 2 & Region 3 (center) \\
\hline$I_{\mathrm{PCBM}} / I_{\mathrm{P} 3 \mathrm{HT}}$ & 1.00 & 1.01 & 1.02 \\
${\mathrm{P} 3 \mathrm{HT}^{*}}^{*} \mathrm{PCBM}$ & $1: 0.94$ & $1: 0.95$ & $1: 1.03$ \\
\hline
\end{tabular}

P3HT ${ }^{*}:$ P3HT $+10 \mathrm{wt} \%$ HOC-P3HT-COH

1: 0.94 (region 1), 1:0.95 (region 2), and 1:1.03 (region 3) (Table 2). These values are close to the P3HT/PCBM ratio $(1: 0.91)$ in solution if the absorption of $10 \%$ HOC-P3HT$\mathrm{COH}$ is taken into consideration.

To examine how the $\mathrm{P} 3 \mathrm{HT} / \mathrm{PCBM}$ ratio affects performance of polymer solar cells in the different regions of the same substrate, an ITO substrate is patterned in the form as illustrated in inlet of Figure 6. Five devices are symmetrically designed on a $2 \mathrm{~cm} \times 3 \mathrm{~cm}$ substrate. As shown in Figure $6, J_{\mathrm{sc}}$ of devices with $10 \%$ HOC-P3HT-COH in the active layer are all higher than those without HOC-P3HT-COH, respectively. It has been shown [13] that reduction of PCBM aggregation is one of the factors leading to higher $J_{\mathrm{sc}}$ value in a polymer solar cell with HOC-P3HT-COH in the active layer. Moreover, thermal stability of the $\mathrm{P} 3 \mathrm{HT} / \mathrm{PCBM}$ layer is also improved with addition of HOC-P3HT-COH in the $\mathrm{P} 3 \mathrm{HT} / \mathrm{PCBM}$ layer.

In this study, consistency of device performance in different regions on a $2 \mathrm{~cm} \times 3 \mathrm{~cm}$ substrate has been improved as shown in Tables 3 and 4 . Standard deviation of $J_{\mathrm{sc}}$, $V_{\mathrm{oc}}$, FF, and $\eta$ for the devices (devices $1-5$ as illustrated in Figure 6) with HOC-P3HT-COH in the active layer is all lower than that without HOC-P3HT-COH in the active layer, respectively. These results reveal that incorporation of HOC-P3HT-COH as compatibilizer improves performance deviation of devices in a $2 \mathrm{~cm} \times 3 \mathrm{~cm}$ substrate, which is
TABLE 3: Solar cells performance of P3HT/PCBM (1:1) based polymer solar cells in different regions of a $2 \mathrm{~cm} \times 3 \mathrm{~cm}$ substrate. The active layer is thermally treated at $150^{\circ} \mathrm{C}$ for 10 minutes.

\begin{tabular}{lcccc}
\hline (a) P3HT/PCBM & $J_{\mathrm{sc}}\left(\mathrm{mA} / \mathrm{cm}^{2}\right)$ & $V_{\mathrm{oc}}(\mathrm{V})$ & $\mathrm{FF}$ & $\eta(\%)$ \\
\hline Region 1 & 7.49 & 0.66 & 0.62 & 3.07 \\
Region 2 & 7.52 & 0.66 & 0.63 & 3.13 \\
Region 3 & 8.22 & 0.64 & 0.63 & 3.29 \\
Region 4 & 8.13 & 0.64 & 0.63 & 3.28 \\
Region 5 & 7.47 & 0.65 & 0.6 & 2.93 \\
\hline Average value & 7.77 & 0.65 & 0.62 & 3.14 \\
Standard deviation & 0.375 & 0.010 & 0.013 & 0.151
\end{tabular}

TABLE 4: Solar cells performance of P3HT/HOC-P3HT$\mathrm{COH} / \mathrm{PCBM}(1: 0.1: 1)$ based polymer solar cells in different regions of a $2 \mathrm{~cm} \times 3 \mathrm{~cm}$ substrate. The active layer is thermally treated at $150^{\circ} \mathrm{C}$ for 10 minutes.

\begin{tabular}{lcccc}
\hline P3HT/PCBM/10\% & $J_{\text {sc }}\left(\mathrm{mA} / \mathrm{cm}^{2}\right)$ & $V_{\mathrm{oc}}(\mathrm{V})$ & $\mathrm{FF}$ & $\eta(\%)$ \\
HOC-P3HT-COH & 9.56 & 0.64 & 0.6 & 3.66 \\
\hline Region 1 & 9.89 & 0.64 & 0.6 & 3.79 \\
Region 2 & 9.75 & 0.64 & 0.61 & 3.77 \\
Region 3 & 10 & 0.64 & 0.59 & 3.77 \\
Region 4 & 9.27 & 0.63 & 0.61 & 3.56 \\
Region 5 & 9.70 & 0.64 & 0.60 & 3.71 \\
Average value & 0.289 & 0.005 & 0.008 & 0.098 \\
Standard deviation & & & &
\end{tabular}

highly related to $\mathrm{P} 3 \mathrm{HT} / \mathrm{PCBM}$ ratio across the substrate. As mentioned previously, the $\mathrm{P} 3 \mathrm{HT} / \mathrm{PCBM}$ ratio has a high deviation from the center of the substrate $(1: 0.85)$ to the edge of the substrate $(1: 1.22)$ without HOC-P3HT-COH in the 
film (Table 1). This deviation is diminished by addition of HOC-P3HT-COH to the P3HT/PCBM layer (Table 2) that matches the results from the device performance as shown in Tables 3 and 4 . A high performance polymer solar cell with an average of $3.71 \%$ power conversion efficiency and low standard deviation under AM1.5G irradiation is prepared with 10\% HOC-P3HT-COH in P3HT/PCBM $(1: 1)$.

\section{Conclusions}

Compositions of P3HT/PCBM in a $2 \mathrm{~cm} \times 3 \mathrm{~cm}$ have been found to be inconsistent from the center part of substrate to the edge of the substrate. Concentration of PCBM tends to be higher on the edge of substrate. This can be solved by adding a hydroxyl group end-functionalized P3HT as a compatibilizer to the P3HT and PCBM. Composition variation across the substrate becomes consistent across the substrate. This will possibly improve the performance of a large area polymer solar cell because of homogeneous distribution of $\mathrm{P} 3 \mathrm{HT} / \mathrm{PCBM}$ on the substrate.

\section{Conflict of Interests}

The authors declare that there is no conflict of interests regarding the publication of this paper.

\section{Acknowledgments}

This work is supported by Ministry of Science and Technology of Taiwan (MOST 103-2113-M-030-005). Financial supports from Academia Sinica of Taiwan (Sustainability Science Project AS-103-SS-A02) and also from the Fu Jen Catholic University are also appreciated. Ping-Tsung Huang likes to thank Professor Chin-Tin Chen and Mr. Yu-Jui Huang (Institute of Chemistry, Academia Sinica) for assistance in device fabrication.

\section{References}

[1] N. S. Sariciftci, D. Braun, C. Zhang et al., "Semiconducting polymer-buckminsterfullerene heterojunctions: diodes, photodiodes, and photovoltaic cells," Applied Physics Letters, vol. 62, no. 6, pp. 585-587, 1993.

[2] K. R. Graham, C. Cabanetos, J. P. Jahnke et al., "Importance of the donor:fullerene intermolecular arrangement for high-efficiency organic photovoltaics," Journal of the American Chemical Society, vol. 136, no. 27, pp. 9608-9618, 2014.

[3] G. Yu, J. Gao, J. C. Hummelen, F. Wudl, and A. J. Heeger, "Polymer photovoltaic cells: enhanced efficiencies via a network of internal donor-acceptor heterojunctions," Science, vol. 270, no. 5243, pp. 1789-1791, 1995.

[4] H. Hoppe and N. S. Sariciftci, "Morphology of polymer/fullerene bulk heterojunction solar cells," Journal of Materials Chemistry, vol. 16, no. 1, pp. 45-61, 2006.

[5] D. Chirvase, J. Parisi, J. C. Hummelen, and V. Dyakonov, "Influence of nanomorphology on the photovoltaic action of polymer-fullerene composites," Nanotechnology, vol. 15, no. 9, pp. 1317-1323, 2004.
[6] J. Huang, G. Li, and Y. Yang, "Influence of composition and heat-treatment on the charge transport properties of poly(3hexylthiophene) and [6,6]-phenyl $\mathrm{C}_{61}$-butyric acid methyl ester blends," Applied Physics Letters, vol. 87, no. 11, Article ID 112105, 2005.

[7] A. Baumann, J. Lorrmann, C. Deibel, and V. Dyakonov, "Bipolar charge transport in poly(3-hexyl thiophene)/methanofullerene blends: a ratio dependent study," Applied Physics Letters, vol. 93, no. 25, Article ID 252104, 2008.

[8] E. Verploegen, R. Mondal, C. J. Bettinger, S. Sok, M. F. Toney, and Z. Bao, "Effects of thermal annealing upon the morphology of polymer-fullerene blends," Advanced Functional Materials, vol. 20, no. 20, pp. 3519-3529, 2010.

[9] M. Sanyal, B. Schmidt-Hansberg, M. F. G. Klein et al., "Effect of photovoltaic polymer/fullerene blend composition ratio on microstructure evolution during film solidification investigated in real time by X-ray diffraction," Macromolecules, vol. 44, no. 10, pp. 3795-3800, 2011.

[10] M. A. Ruderer, R. Meier, L. Porcar, R. Cubitt, and P. MüllerBuschbaum, "Phase separation and molecular intermixing in polymer-fullerene bulk heterojunction thin films," Journal of Physical Chemistry Letters, vol. 3, no. 6, pp. 683-688, 2012.

[11] W.-H. Baek, T.-S. Yoon, H. H. Lee, and Y.-S. Kim, "Composition-dependent phase separation of P3HT:PCBM composites for high performance organic solar cells," Organic Electronics: physics, materials, applications, vol. 11, no. 5, pp. 933-937, 2010.

[12] P. Qin, G. Fang, N. Sun et al., "Composition-dependent phase separation effects of organic solar cells using P3HT: PCBM as active layer and chromium oxide as hole transporting layer," Applied Surface Science, vol. 257, no. 9, pp. 3952-3958, 2011.

[13] Y.-H. Chen, P.-T. Huang, K.-C. Lin, Y.-J. Huang, and C.-T. Chen, "Stabilization of poly(3-hexylthiophene)/PCBM morphology by hydroxylgroup end-functionalized $\mathrm{P} 3 \mathrm{HT}$ and its application to polymer solar cells," Organic Electronics, vol. 13, no. 2, pp. 283-289, 2012.

[14] T.-A. Chen, X. Wu, and R. D. Rieke, "Regiocontrolled synthesis of poly(3-alkylthiophenes) mediated by Rieke zinc: their characterization and solid-state properties," Journal of the American Chemical Society, vol. 117, no. 1, pp. 233-244, 1995.

[15] K. Norrman, A. Ghanbari-Siahkali, and N. B. Larsen, "Studies of spin-coated polymer films," Annual Reports on the Progress of Chemistry-Section C, vol. 101, pp. 174-201, 2005.

[16] F. Padinger, R. S. Rittberger, and N. S. Sariciftci, "Effects of postproduction treatment on plastic solar cells," Advanced Functional Materials, vol. 13, no. 1, pp. 85-88, 2003.

[17] T. J. Savenije, J. E. Kroeze, X. Yang, and J. Loos, “The effect of thermal treatment on the morphology and charge carrier dynamics in a polythiophene-fullerene bulk heterojunction," Advanced Functional Materials, vol. 15, no. 8, pp. 1260-1266, 2005.

[18] M. Reyes-Reyes, K. Kim, and D. L. Carroll, "High-efficiency photovoltaic devices based on annealed poly(3-hexylthiophene) and 1-(3-methoxycarbonyl)-propyl-1-phenyl-(6,6) $\mathrm{C}_{61}$ blends," Applied Physics Letters, vol. 87, no. 8, Article ID 083506, 2005.

[19] G. Li, V. Shrotriya, J. Huang et al., "High-efficiency solution processable polymer photovoltaic cells by self-organization of polymer blends," Nature Materials, vol. 4, no. 11, pp. 864-868, 2005.

[20] S. E. Shaheen, C. J. Brabec, N. S. Sariciftci, F. Padinger, T. Fromherz, and J. C. Hummelen, " $2.5 \%$ efficient organic plastic 
solar cells," Applied Physics Letters, vol. 78, no. 6, pp. 841-843, 2001.

[21] D. Chirvase, J. Parisi, J. C. Hummelen, and V. Dyakonov, "Influence of nanomorphology on the photovoltaic action of polymer-fullerene composites," Nanotechnology, vol. 15, no. 9, pp. 1317-1323, 2004. 

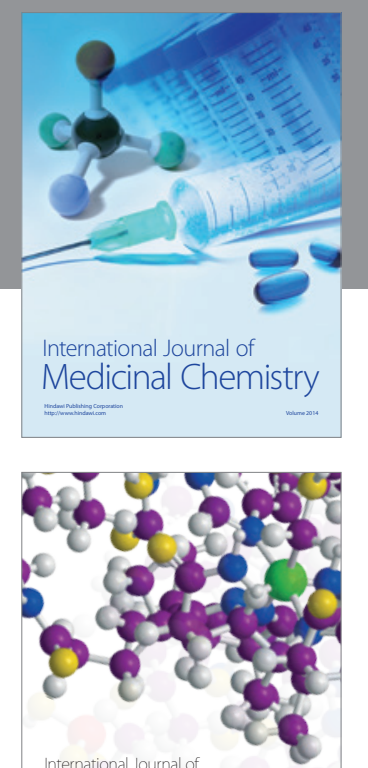

\section{Carbohydrate} Chemistry

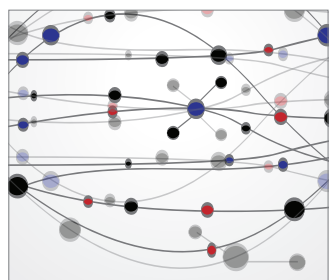

The Scientific World Journal
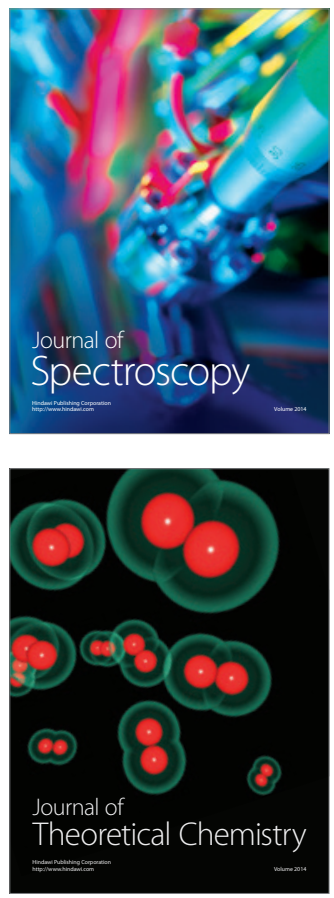
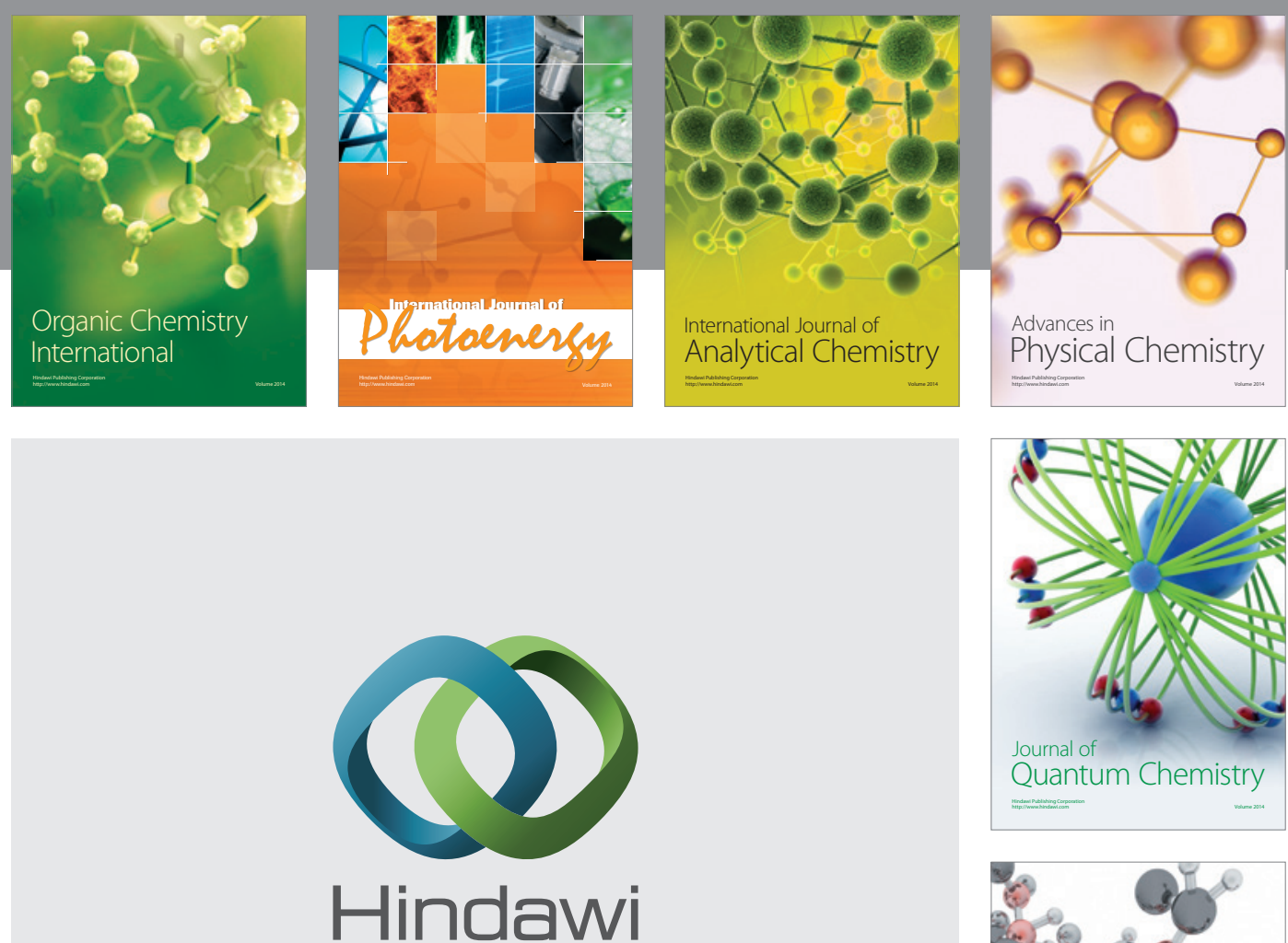

Submit your manuscripts at

http://www.hindawi.com

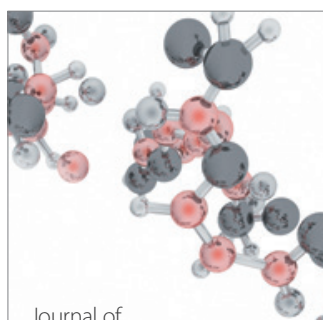

Analytical Methods

in Chemistry

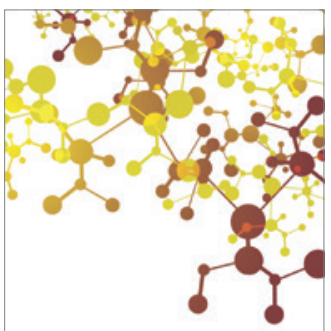

Journal of

Applied Chemistry

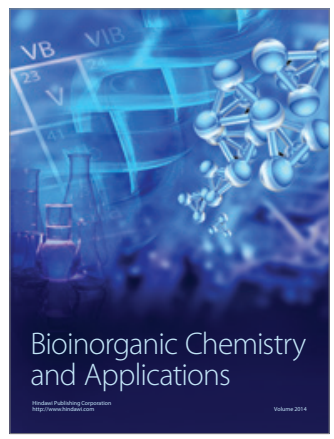

Inorganic Chemistry
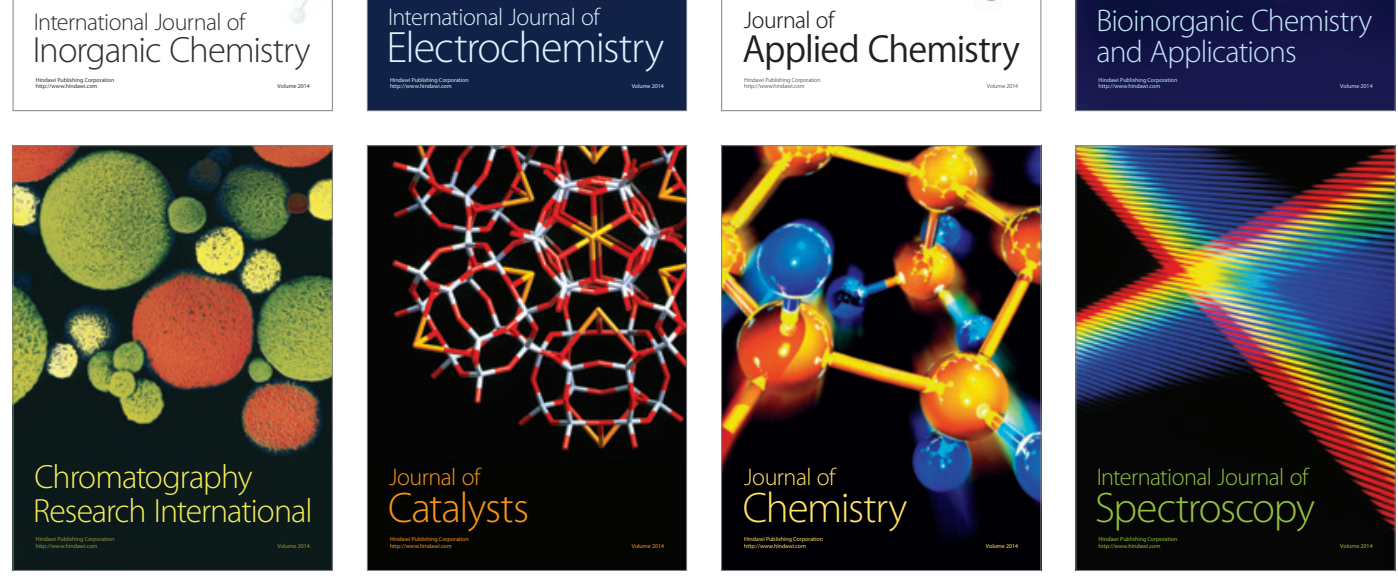